\title{
Philosophical and societal elements of human upbringing
}

\section{[Filozoficke a spolocenske aspekty vychovy cloveka]}

\author{
Jan Danek
}

DOI: 10.18355/XL.2019.12.04.06

\begin{abstract}
The study is focused on analysis of topical issues of creating human personality. The author's base is on the theory of philosophy of education and in particular on its importance. The text gradually resolves the philosophy of man in relation to the nature and the society, the philosophy of education and the philosophy of pedagogy as educational science. The summary of meanings of the philosophy of education links the human being with nature and society and with socialization of man and his decent life. Formation of man's personality is connected with the education and training as part of culture, analysis of the conditions of existence of the contemporary world with the need of natural activities and responsibility of educators and those who are brought up. From the aspect of the educational philosophy, educational context is bound to global issues, which we can deduce the content and orientation of education and training within a national scale from. The study also addresses the need to analyze the position and importance of man in human life and in the world in meaning of his naturalness, offers the solution for the development of man and his place in the society based on his natural growth influenced by heredity, environment and education.
\end{abstract}

Key words: man, upbringing, education, character, humanity, naturalness, society, life, wisdom, values

\begin{abstract}
Anotácia
Predkladaná štúdia sa zameriava na analýzu problematiky vytvárania l’udskej osobnosti zdôrazňovaním významu teórie vzdelávania. Autor poukazuje na priblíženie filozofie vzdelávania, ako aj na vymedzenie vzt’ahu človeka k spoločnosti a k prírode. Formovanie osobnosti človeka je spojené so vzdelávaním, ktoré možno považovat' za súčast' kultúry, a preto je potrebná aj analýza podmienok existencie súčasnej spoločnosti. Z hl'adiska filozofie vzdelávania sa vzdelávací kontext viaže na globálne problémy odzrkadl'ujúce sa aj $\mathrm{v}$ existujúcich výchovno-vzdelávacích koncepciách. Centrum pozornosti štúdie smeruje $\mathrm{k}$ analýze postavenia a významu človeka $\mathrm{v}$ l'udskom svete. Autor rovnako predkladá aj možnosti rozvoja človeka a jeho pozície v spoločnosti prostredníctvom charakterizovania prirodzeného rozvoja l'udskej osobnosti ovplyvňovanom hlavne dedičnost'ou, prostredím a vzdelaním.

Kl'účové slová: človek, hodnoty, charakter, l'udskost', múdrost', prirodzenost', spoločnost', výchova, vzdelávanie, život

\section{Filozofické a spoločenské aspekty výchovy človeka}

Človek, uznávaný, ale často aj zanedbávaný subjekt spoločenského života, $\mathrm{s}$ ktorým sa, z úrovne vlastných alebo riadiacich štruktúr, počíta ako s vykonávatel'om úloh alebo prostriedkom pre dosiahnutie určitých stanovených úloh. V dejinnom vývoji sa výrazne pozície človeka menili, čo bolo a je badatel'né aj v procesoch výchovy a vzdelávania. Najskôr to boli prístupy fixácie, potom prispôsobovanie, nasledovali postupy formovania a nakoniec, od cca polovice 20. storočia prístupy tvorby (Kudlacova 2009) so zdôrazňovaním schopností, možností, ale aj prirodzenej dynamiky každého človeka. Človeka, ktorý je charakterizovaný ako „subjekt historického procesu vývoja materiálnej a duchovnej kultúry na Zemi, biosociálna
\end{abstract}


bytost' (predstavitel' druhu homo sapiens) geneticky súvisiaca s inými formami života, ktorá sa z nich vyčlenila vd’aka schopnosti vyrobit' pracovné nástroje. Vyznačuje sa artikulovanou rečou, myslením a vedomím (Frolov 1986). Hodnotenie človeka v zmysle duchovnej bytosti znamená prejav schopnosti a rešpektovania myslenia a s ním spojeného hl'adania lepších a prijatel'nejších podmienok pre život, ktorý významne ovplyvňuje vzdelávanie a výchova. Je jednoznačné a objektívne tvrdenie, že vzdelávanie i výchova prispievajú k zdokonal'ovaniu života človeka počas jeho dejinného vývoja. Toho života, ktorý je vo všeobecnej rovine definovaný ako ", pretrvávanie humanizovaných foriem existencie prírody a spoločnosti, ktoré l’udská civilizácia do súčasnosti dosiahla“ (Steindl 2000). Človek je v tomto zmysle subjektom, čiže ovplyvňovatel'om dejín, ktorý zdôrazňuje nutnost' slobody, rozumu, potrebu učit' sa z minulosti v záujme rozvoja súčasnosti i perspektív budúcnosti. Prirodzenost' človeka je prejavovaná ako túžba po budúcnosti, št’astí, mravnosti, tvorbe,mieri ale aj v zabúdaní historických skúseností. Preto l'udia, ako celok a človek ako jednotlivec, často strácajú zmysel pre realitu, uvedomovanie si slabostí človeka v záujme jeho životných ciel'ov, presadenia sa alebo mocenských ambícií. , V našom kultúrnom prostredí uvol'ňovanie životných štýlov z pevnejšie stanovených pravidiel sprevádzajú procesy korešpondujúce so zameraním na úspech, pričom sa oslabuje dôraz na etické parametre. Spoločnost' sa stáva tolerantnejšia k l'ud'om, ktorí si nevšímajú etické rozmery správania : lest', podvod, mystifikácia a propagačná (seba) štylizácia, ktoré sú od nepamäti súčast'ou obchodnej taktiky, sa stávajú prejavmi šikovnosti a primeraného prístupu k životu bez toho, aby sa na to negatívne reagovalo" (Sulavikova, 2006). Celkové hodnotenie človeka skúma a rieši filozofická antropológia orientovaná na poznatky a súvislosti o človeku. Skúma nadväznost' obrazu človeka v určitom historickom období, období spoločenských systémov, ale aj vplyv výchovy a vzdelávania na dynamiku a orientáciu života. Filozofická antropológia skúma človeka (Kudlacova 2006) v celej jeho integrite, ale kladie aj otázky o pôvode človeka, zmysle a perspektívach jeho existencie. a. J. Peregrin (2008) sa zamýšl’a nad prejavmi človeka a v tejto nadväznosti konštatuje, že v dielach filozofov je možné nájst' celý rad faktov o človeku, ktorými sú „,vedomie, mysel', rozum, jazyk, kultúra, umenie, náboženstvo... Podstatné je, či sa niečím z toho človek od iných tvorov odlišuje kvalitatívne, alebo či ide len o rozdiely kvantitatívne. Ak povieme napríklad, že človek je rozumný živočích znamená to, že ho jeho rozum robí so všetkými ostatnými tvormi nejak nesúmeritel'ným, alebo len to, že je z hl'adiska inteligencie na jednej strane spektra, na ktorého druhom konci sú možné prvoky“. Je možné konštatovat', že ,človek je súhrnne biologický organizmus na najvyššom stupni prirodzeného vývoja živej hmoty na Zemi, najvyššie organizovaná forma života disponujúca schopnost'ou sebareflexie a určovaná psychosociálnymi faktormi evolúcie, subjekt historického utvárania spoločenských vzt’ahov, ktorý je nadaný rozumom, vedomím, rečou, plne socializovaná bytost' schopná vyrábat' a užívat' nástroje k pretváraniu svojich životných podmienok, tvorca hodnôt, seba samého i svojho spoločenského bytia, dejín a kultúry podiel'ajúcej sa na všetkých ekologických i medzil'udských interakciách“ (Malá československá encyklopédia, 1984). Na druhej strane je nutné prijímat’ aj iné názory na vnímanie človeka, v zmysle orientácie a úloh globálnej výchovy, medzi ktorými sa uvádza aj potreba uvedomovania si skutočnosti, že neexistuje len jeden názor na svet, a že je potrebné rešpektovat' a uznávat' aj iné názory na život a svet. Aj v tomto zmysle sa prejavuje prirodzenost' človeka $\mathrm{v}$ záujme hl'adania metód a prostriedkov poznania, vzdelávania, ktoré vedú k výraznejšej humanizácii a demokratizácii života a spoločnosti. J. Ch.Korec (2007) uvažuje, v súvislostiach s človekom, že „nemôžeme preto prírodovedecky nijako negovat' transcendentný charakter človeka. Skutočnost', že človek prevyšuje prírodu a biológiu a že na rozdiel od všetkých ostatných živých bytostí má schopnost' mysliet', projektovat', volit' si a rozhodovat' sa i zaujímat'

XLinguae, Volume 12, Issue 4, October 2019, ISSN 1337-8384, eISSN 2453-711X 
postoje, ktoré nie sú viazané nijakou biologickou nevyhnutnost'ou, to všetko sa prejavuje v osobnom vedomí človeka, v jeho slobode, v jeho myslení, v mravnom zmýšl’aní, vo vedomí zodpovednosti za rozhodnutia a činy, v náboženských postojoch, v umení, atd'.“

Sú to prejavy hodnôt, záujmov a potrieb, ktoré sú prirodzene spojené s kvalitou života, socializáciou, rodinou, vlastnými túžbami o sebarealizáciu i objektívne uznanie, či docenenie ako prejav životných snáh a ciel'ov. Už samotný obraz človeka sa stáva výrazným vedeckým faktom a záujmom, lebo človek, ako jedinec i súčast' spoločenského kolektívu,

prináša do života konkrétne hodnoty, ktoré sú výsledkom citov, prežívania, skúseností, tvorivosti, aktivity, individuálnosti i kolektívnosti. Každý človek má preto svoje miesto a význam v spoločenskom živote, lebo vlastnými aktivitami, viac alebo menej ovplyvňuje, spoločenský život civilizácií alebo národov. V tomto by mal byt' základ pre presadzovanie rovnosti a rešpektu medzi l’ud'mi „lebo zásadná jednota l'udstva v mätúcej mnohosti vonkajších prejavov má dnes vel'ký význam. Berie totiž pôdu pod nohami každému rasizmu, predsudkom o domnele biologických, t.j. nezmenitel'ných rasách, rozdielne hodnotených. Práve preto je tak dôležité pochopit', že mnohopočetné štiepenie l'udstva je v skutočnosti výsledkom komplikovaného historického procesu v temnom dávnoveku, o ktorom vieme tak málo“ (Geiss 2005, 32).

Pri hl’adaní objektívneho a reálneho prístupu k výchove a vzdelávaniu, je potrebné vychádzat' z uceleného poznania podstaty človeka, jeho vývoja, biologickej a spoločenskej podstaty i hodnotenia $\mathrm{v}$ individuálnej i kolektívnej podstate. Zároveň nachádzat' možnosti, ale zlepšit' aj medzil'udské vzt'ahy snád' aj uvažovaním nad potrebou obsahového naplnenia známeho výroku nositel'a Nobelovej ceny za mier M. L. Kinga, ktorý konštatoval, že ,naučili sme sa lietat' ako vtáky v povetrí, naučili sme sa plávat' ako ryby v mori, ale nenaučili sme sa žit' ako l'udia s l'ud'mi“. Skutočnost', ktorá, na základe poznania človeka, podnecuje d’alšie úvahy o procesoch výchovy a vzdelávania, ktoré $v$ najvšeobecnejších súvislostiach rieši filozofia výchovy. Významami filozofie výchovy, sú fakty, že filozofia výchovy obsahuje filozofiu človeka, obsahuje filozofiu procesov výchovy človeka a zároveň aj filozofiu pedagogiky ako vedeckej teórie a disciplíny (Zelina 2004).

$\mathrm{Z}$ aspektu výchovy, ako jedného $\mathrm{z}$ faktorov formovania osobnosti človeka, v nadväznosti na prostredie a dedičnost', je nutné rešpektovat' jeho potreby, schopnosti i perspektívy, o ktorých M. Čič (2001) konštatoval, že ,rámec a všeobecne prijatel'ný program budúcnosti l'udstva, založenej na uznaní človeka ako najvyššej hodnoty predpokladá taký praktický a ekonomický systém, ktorý poskytne priestor na slobodu každému občanovi limitovaný len zásadou, že sloboda jedného je dovtedy mravná a zákonná, ak neobmedzuje práva a slobodu druhého“. Slobodu chápeme ako priestor pre vol'né vyjadrovanie názorov, stanovísk, presvedčenia alebo konania spojeného so zodpovednost'ou a dôstojnost'ou. Dôstojnost' je vnímaná ako najvyššia hodnota, ktorú nemožno zamenit' ani politicky, ani ekonomicky, lebo je prejavom vôle a životnej spokojnosti každého človeka bez obmedzujúceho vplyvu iného. V týchto podmienkach a súvislostiach sa formuje osobnost', ktorá znamená „istú jednotu vnútorných predpokladov a vonkajších vplyvov utváranú psychickou realitou človeka"'(Kovac 2002).

Osobnost' sa prejavovala a prejavuje v súvislosti s celkovým konaním i rozhodovaním každého jednotlivca, pričom má výrazný vplyv a podiel výchova, v procese ktorej sa utvárajú vzt’ahy a postoje viazané predovšetkým na charakter ako vlastnost', ktorou sa prejavujú vzt’ahy jednotlivca k iným l’ud'om, práci i sebe samému. Práve výchova prispieva k výraznej socializácii každého jednotlivca v súlade s jeho predpokladmi a aktivitou, k čomu W. Brezinka ( 1996, 48 ) uvádza, že „zmysel každej výchovy je vtom, aby sme vychovávanému pomohli získat' osobnostné vlastnosti, ktoré ho uschopnia na samostatný a sociálne zodpovedný 
život“. Samostatný a sociálne zodpovedný život je viazaný na poznávanie reality prostredia a jeho spájania s ideálmi životnej cesty jednotlivca spojenej s podstatnými hodnotami života vyjadrujúcimi prirodzený záujem o život človeka. Týmito záujmami človeka je zdravie, práca, rovnost', spolupráca, spoločenské podmienky, kultúra, uznanie a d'alšie oblasti viazané na št’astie človeka. Reálnost' výchovy bola a je predovšetkým viazaná na skutočnú osobnost' človeka vnímajúceho a hodnotiaceho realitu a podl'a tohto vnímania i hodnotenia sa aj správat' $\mathrm{v}$ súlade so životnou skutočnost'ou a predstavami. Uvedenú líniu zachytáva definícia výchovy, ktorú J. Pelikán (2007) predstavuje ,ako predovšetkým využívanie a vytváranie životných situácií, v ktorých prichádzajú vychovávaní priamo z logiky situácie k určitým záverom, ktoré nie sú len prevzaté, ale upevnené zážitkom“. A výchova i vzdelávanie zážitkom začína vtedy, ak je vytváraný bezprostredný kontakt a spojenie so svetom, ale aj so sebou samotným v prejavoch správania či interpretácie javov. Kontakt s realitou zvyšoval a zvyšuje záujem o existujúce hodnoty, zvedavost', hl'adanie, myslenie či porovnávanie. Aby v tomto zmysle bola výchova životná a nie ideálna, je potrebná kvalitná realizácia vzdelávania, ktoré je vedomostným základom pre proces výchovy. Vzdelávanie a vzdelanie, proces a výsledok, predstavujú súhrn poznatkov a vedomostí o prírode, spoločnosti a človeku v spojení s konkrétnymi pracovnými i spoločenskými schopnost'ami, zručnost'ami a pohl'adom zodpovedajúcim kultúre danej epochy. S osvojovaním systému vedomostí a schopností chápe vzdelaný človek vzt'ahy medzi poznatkami, získava schopnosti používat' svoje poznanie pri riešení nových úloh a schopnosti d’alšieho sebavzdelávania. Vzdelanie je zároveň aj hrádzou proti zneužívaniu, ovládaniu a vykoristovaniu človeka človekom v zmysle utvárania jeho kultúrnej identity. „ Kultúrnu identitu môžeme definovat' ako súhrn postojov, návykov, tradícií, hodnôt, interpretácií a sebainterpretácií, spôsobov myslenia, cítenia a konania ( vzorcov správania), ktoré charakterizujú istú komunitu“ (Visnovsky, 2007).

Vzdelanost' je prirodzenou hodnotou a potrebou každého človeka v záujme jeho slobody a dôstojnosti, lebo negramotným l’ud'om je znižovaná ich sloboda, dôstojnost', l'udská čest', ale predovšetkým podmienky demokracie a humanizmu. Vzdelávanie a jeho výsledok, všeobecné a odborné vzdelanie, znamená aj osvojovanie si estetických i morálnych hodnôt, vytváranie určitého postoja k svetu, spoločnosti i sebe samému. Cez vzdelávanie a vzdelanie prichádzajú l'udia k múdrosti, ktorá znamená integrovanú jednotu rozumu a charakteru (Ruisel 2005). Preto je, podl’a J. Skalkovej (2007), v súlade s potrebami človeka i dynamickej spoločnosti ,, je nutné ciele vzdelania stále znovu analyzovat' a objasňovat' v meniacom sa spoločenskom vývoji a hodnotit' ich v určitých spoločenských podmienkach“.

Vzdelanie významne aktivizuje nielen výchovné pôsobenie i sebavýchovu, lebo výchova bez poznatkov, vedomostí a nepoznania súvislostí sa stáva dogmatickou líniou s nízkou úrovňou presvedčovania. Ale vzdelanie môže byt' hrádzou aj ideológii, ktorej zámerom nie je realitu poznávat', ale ju predovšetkým ovládat'. Lebo, ako uvádza N. Pelcová (2010) „, premena sveta a poriadku l'udských hodnôt a obrovská spoločenská mobilita otvorili a spochybnili pevné a nemenné paradigmy. Ciel' výchovy nie je v pokračovaní a prevzatí tradície, ale v dosiahnutí niečoho nového, vyššieho. Cestou k ciel'u je spoločenský pokrok a individuálny úspech“. To niečo nové a spoločenský pokrok a individuálny úspech je dynamika samostatnej osobnosti s nezávislým myslením, či konaním, ale so zodpovednost’ou za realizované aktivity, získanie pozície na základe vlastných schopností a úsilia a nezávislosti od ideologického a politického smerovania spoločnosti v zmysle významu vzdelania. Prirodzenou túžbou a snahou človeka je práve sloboda a nezávislost' viazaná jednak na proces vzdelávania a s využitím vzdelania aj v procese výchovy (Sirotová, 2018). Nie je možné, v zmysle podstaty človeka, aby bol postavený do pozície len objektu pôsobenia, ale aj ako aktívny subjekt s prejavom vlastnej vôle, aktivity, činov,

XLinguae, Volume 12, Issue 4, October 2019, ISSN 1337-8384, eISSN 2453-711X 
komunikácie či rozhodovania. Pri vnímaní človeka ako subjektu nie je preto možné aby bol použitý len ako prostriedok k dosiahnutiu iného ciel’a práve tak ako príroda nemôže byt' chápaná len ako surovinový zdroj (Pelcova, 2010). Človek musí byt' teda, prostredníctvom výchovy a vzdelávania, kultivovanou osobnostou, ktorú B. Kosová (2013) so snahou , usilovat' o výchovu autentickej, nekonformnej osobnosti, ktorá si je vedomá svojich možností, schopností aj svojich ideálov, ale aj potrieb iných a sveta, ktorá je schopná slobodne, ale pritom zodpovedne a mravne riadit' vlastný život, ktorá je zaujatá osobnými plánmi a zároveň angažovaná pre zlepšenie života spoločnosti.“ Človek chce byt' slobodný, tvoriaci hodnoty s príslušným dôstojným ocenením s vidinou štastia svojho najbližšieho prostredia (rodiny, kolegov, rovesníkov) a príroda musí byt' chápaná ako základ života na Zemi, o ktorú sa treba starat', len zásahy človeka do nej už znemožňujú jej samoreguláciu a regeneráciu. Vzdelanie $\mathrm{v}$ týchto súvislostiach znamená prístup k všetkému l’udskému poznaniu, vyššiu pracovnú výkonnost', lepšiu ochranu životného prostredia, výraznejšiu ochranu zdravia, výraznejšiu spoločenskú angažovanost', spoločenskú a politickú stabilitu, výraznejší kultúrny život a komunikáciu (Our Creative diversity, 1995). Ale aj výraznejšiu potrebu starostlivosti o dôstojnost' človeka a l'udí ako celku. Príkladom môžu byt' zamestnanci, ktorí síce pracujú, ale výplatu nedostanú a nikoho netrápi ich d'alší osud. Potom je potrebné uvažovat' nad spoločenskou spravodlivostou politického i ekonomického systému, ktorý má slúžit' všetkým. Zabezpečenie perspektívy Zeme i človeka, v súlade s jeho spoločenskými potrebami, ale aj potrebami ochrany prírody je potrebné, prostredníctvom výchovy, eliminovat' dopad ôsmich smrtel'ných hriechov človeka. K. Lorenz (1990) ich predstavuje nasledovne:

1. Prel'udnenie Zeme a tým rast nezáujmu o osudy iných l'udí.

2. Devastácia prostredia, neschopnost' regenerácie prírody, umieranie biocenóz.

3. Uponáhl'anost' doby s dôsledkom podlamovania zdravia súčasného človeka.

4. Vyhasnutie citov s dôsledkom miznutia citových vzt'ahov k l'ud'om, zvieratám i veciam.

5. Genetický úpadok, ktorý sa prejavuje normami nárokov, získavanie bez zvýšenej námahy, strácaním zmyslu pre zodpovednost'.

6. Rozchod s tradíciou prejavujúci sa vo vzt'ahoch detí a rodičov.

7. Rastúca poddajnost' voči doktrínam prejavujúca sa v strate autentičnosti, neovládaní voči názorovej jednote, či uniformite.

8. Dezintegrácia osobnosti človeka a strata jeho individuality pri hrozbe jadrovej katastrofy.

Z hl'adiska budúcnosti človeka, jeho rozvoja i odstraňovania uvedených nedostatkov je nutné zdôrazňovat' silu a dynamiku výchovy a vzdelávania, ktoré ale nie sú všemocné. lebo predstavené nedostatky je nutné riešit' v súlade s celkovým chápaním človeka, ktorý je v podstate dobrý a uvedenú danost' je potrebné rozvíjat'. Prejavuje sa potreba analýzy príčin negatívnych javov súčasného života i hladania metód ich odstránenia. Je to životný štýl, nekontrolovaná globalizácia, nedostatok informácií o živote civilizácií, krízových prejavoch, nepochopenie podstaty prírody $\mathrm{z}$ hl'adiska budúcnosti života, či nedostatočné vnímanie človeka v celom systéme svetových hodnôt a orientácie. Ukazuje sa nutnosti porovnávania, získavania podnetov z jednej civilizácie pre druhú a tým sa vyhýbat' stretu civilizácií, porovnávat' ekonomický rozvoj, globalizačné tendencie, ale aj jednoznačnú pozíciu vychovávaných v týchto procesoch poznávania. Porovnávania na základe otázky, či má vychovávatel' právo vnucovat' vychovávanému svoje pozície a názory, pri poznaní nutnosti autentickosti či samostatnosti každého človeka, pričom je nutné potláčat', prípadne odstraňovat' konformnost', lebo ,, konformný spôsob života sa 
považuje za výsledok neslobody človeka prejavovat' sa autenticky, pričom sloboda znamená autonómne sa v živote rozhodovat' a pristupovat' tvorivo ku svojim vzt'ahom k prostrediu“" (Sulavikova, 2006)

B. Kosová $(2008$, 22) uvádza, že ak je filozofia sústavou kritického uvažovania o otázkach poznávania a konania, potom „filozofia edukácie je odhal'ovanie, vysvetl'ovanie a zdôvodňovanie zmyslu edukácie, nastol'uje základné otázky jej povahy a predpokladov, jej chápania a hodnotenia, usiluje sa o zachytenie jej podstaty, teda čo je edukácia a aké sú jej štruktuálne súvislosti“. Metodologické otázky výchovy sú spojené sobjektivitou a primeranost'ou vplývania na vychovávaného zhl'adiska autoritatívneho prístupu, liberálneho prístupu alebo demokratického prístupu. Je to výsledok celkového poňatia ciel’a výchovy, ale aj prototypu osobnosti, ktorá má mat' samostatné a zodpovedné konanie. Pri hodnotení primeraných foriem, metód a prostriedkov výchovy je nutné viazat' sa aj na perspektívnu osobnost' vychovávaného a uvedomovanie si faktu troch prototypov osobností (Kovac 2002), ktorými sú rudimentárna (jednoduchá) osobnost', osobnost' konformná (prispôsobujúca) a osobnost' kultivovaná (samostatná a dôstojná). V súlade v nadväznost'ou vzdelávania a výchovy existuje axióma, že vzdelávanie a výchovu nie jej možné oddelit', lebo aj počas vyučovania sa vychováva a počas výchovného pôsobenia sa aj vzdeláva (Pelcova, 2010). Najdynamickejším a najvhodnejším prístupom k vychovávanému je demokratická výchova viazaná na podstatu, zvedavost', schopnost' i záujem vychovávaného, lebo „podstata človeka sa nachádza mimo všetkého, čo nazývame životom, je v človeku tým najpôvodnejším a prispôsobuje ho k tomu, aby transcendentálnost' seba samého, svoj život i celý život“" (Scheller 1968, 66). Týmto sa učí mysliet', rozhodovat', konat', uvedomovat' si význam vlastnej osobnosti, k čomu je potrebná aj skúsenost' vychovávatel'a, učitel'a, rodiča, ktorá musí obmedzovat' liberálny prístup potvrdil aj pred stovkami rokov výrok J. A. Komenského, ktorý konštatoval, že svetlo poznania je najmúdrejšia zbraň, ktorou sa dá čelit' nevedomosti a z nej prameniacemu zlu. Tomu zlu, ktoré je chápané ako „ úmyselné správanie, ktorého ciel'om je ublížit', zneužit', ponížit', zbavit' l'udskosti alebo zničit' ostatných nevinných l'udí alebo za pomoci úradnej moci či systémových prostriedkov nabádat' ostatných k takýmto činom alebo im ich umožnit'. Znamená to, že zlo je vediet' aj o iných možnostiach správania sa, ale správat' sa zle.“ (Zimbardo, in. Sedová,201).

Historické skúsenosti dokázali, že človek sa nekultivuje len vzdelávaním, ale že je potrebná aj výchova ako organická súčast' pedagogického myslenia a konania. O výchove, ako skutočnej súčasti pedagogiky prvýkrát vedecky uvažoval Herbart už v roku 1806, ked' bolo vydané jeho významné dielo Všeobecná pedagogika odvodená od ciel'a výchovy. Pravda je aj skutočnost', že o výchove, aj ked' ešte necielene, pri uvažovaní nad neduhmi človeka písali už napr. E. Rotterdamský v Chvále bláznovstva alebo J. A. Komenský v diele Všeobecná rozprava o náprave l'udských vecí. Analýzou historických prameňov by sa našlo určite viac autorov, ktorí ale výchovu spájali predovšetkým so vzdelávaním, a vyučovaním na základe potrieb spoločnosti. N. Pelcová (2010) súhlasí s hodnotením výchovy ako „potrebe spoločnosti, v ktorej sa vychovávaný prispôsobuje požiadavkám spoločnosti napodobňovaním vzorov dospelých sa pripravuje na svoju sociálnu, pracovnú i l’udskú pozíciu“. Pri príprave na vlastnú sociálnu, pracovnú i l’udskú pozíciu ale vychovávaný potrebuje poznat' objektívny obraz spoločnosti, jej základy, organizáciu, právne či politické normy, príčiny pozitívnych alebo negatívnych javov sveta, čo mu poskytuje vzdelávanie. Od vychovávaného sa vyžaduje, ako od budúceho zodpovedného občana, rozhl'ad, odvaha, angažovanost', dynamická komunikácia a vlastná zodpovednost'. Prostredníctvom týchto vlastností sa môže snažit' tvorit' podnety ako existujúcu skutočnost' menit' k lepšiemu, kvalitnejšiemu, novšiemu, utvárat' cestu k l'udskosti. Proces výchovy musí byt' teda viazaný na uvažovanie,

XLinguae, Volume 12, Issue 4, October 2019, ISSN 1337-8384, eISSN 2453-711X 
prežívanie, každodenný život a realitu osobnosti pri poznaní jej slabostí či predností tak, aby sa vychovávaný cítil byt' a bol prirodzeným subjektom, aktívnym jednotlivcom a predovšetkým slobodným a dôstojným človekom uvedomujúcim si mieru zodpovednosti voči sebe i ostatným. Zodpovednosti, ktorá je vnímaná ako „výsledok integrácie všetkých psychických funkcií osobnosti: subjektívneho vnímania okolitého sveta, zhodnotenie vlastných životných dispozícií, emocionálneho vzt’ahu k povinnosti, vôl'a“ (Muzdybajev 1983, 135). Ale ,, zodpovednost' je aj to, čo pripadá výhradne mne a čo l'udsky nemôžem odmietnut"“ (Tomasovicova, 2006).

Riešenie problémov správania i rozhodovania, prijímanie hodnôt i prístupy ku kvalite života znamená ucelenost' a kvalitu vzdelania v orientácii na komplexné poznanie, lebo ,povrchnost' a nezanietenost' premenili povahu poznania a vzdelania. Vzdelanie v nivelizovanej dobe stratilo zacielenie $\mathrm{k}$ celku, stratilo túžbu porozumiet' tomu jednému, celku, tomu najdôležitejšiemu, teda zmyslu poznania, zabudlo sa na súvislost' pravého poznania a činu, na poznanie, ktoré zaväzuje“ (Pelcova 2010). Potrebnú ucelenost' poznania jednoznačne vyžaduje prepojenost' prírody, spoločnosti i človeka ako nevyhnutnej línie smerujúcej ku komplexnému zabezpečeniu života a jeho univerzálnosti. Ukazuje sa potreba významnejšieho prepájania vied, k čomu N. R. Sidorov (2007) konštatuje, že „súčasná veda je univerzálna v tom zmysle, že orientujúc sa na všestranný výskum skutočnosti predstavuje súhrn množstva čiastkových vied, každá sa zaoberá svojím predmetom, metódami, kategoriálnym aparátom. A potom každá z nich stanovuje perspektívu videnia sveta, ale ani jedna nezachytáva svet ako taký, každá zachytáva jednu stránku skutočnosti, ale nie skutočnost' ako celok“.

Pri tomto rozpore sa ako vel'mi dôležitá ukazuje otázka pedagogiky ako vedy o výchove a vzdelávaní, čo predstavuje tretí význam filozofie výchovy. Pedagogika prešla a prechádza dynamickým vývojom s rastom jej významu, lebo rieši utváranie najcennejšieho subjektu a hodnoty každej spoločnosti a to osobnosti človeka. Vlastnými metódami skúma efektívne a vhodné postupy pri výchovnej a vzdelávacej práci s človekom od útleho veku po dospelost', ale aj počas nej. Pedagogika analyzuje vhodnost' i zložitost' poznania a poznatkov z aspektu komplexnosti vedomostí, ale aj ich praktického uplatnenia. Paralelne so vzdelávaním je nutné realizovat' aj výchovu ako dôležitý činitel' utvárania osobnosti. Meniace sa podmienky v škole, obci, spoločnosti, rozdielne psychické i fyzické predpoklady vychovávaných, uznávané a presadzované hodnoty, spoločenská morálka a iné faktory poukazujú na zložitost' pedagogického skúmania, lebo pri práci, výchovnej i vzdelávacej práci, neplatia trvalo platné axiómy. V pedagogike by sa mali stretávat' rozličné vedecké prístupy a tak objektivizovat' a sumarizovat' poznanie a potrebné správanie i konanie, lebo v súčasnosti je hlavným objednávatel'om výchovy a vzdelávania spoločnost'. Tá spoločnost', ktorej smerovanie, kvalitu, rozvoj a pozície v nej budú ovplyvňovat', po niekol'kých rokoch, práve žiaci a študenti základných, stredných i vysokých škôl. Preto pedagogika akcentuje spoločenskú normatívnost' a v tomto zmysle sa často mylne hodnotí ako nevedecká, užitá disciplína .

Ale spochybňovanie pedagogiky ako vedy je prejavom spochybňovania možností utvárania osobnosti človeka, možností jeho kultivácie a zdokonal'ovania v smere l'udskosti, lebo R. Palouš (1991) vkladá nádej do výchovy, a pedagogiky vôbec, slovami, že ,výchova je nová nádej, že sa l’udstvo obráti k svojim povinnostiam, k pravej l'udskej poctivosti“". Pedagogika je súčast’ou dejinného vývoja človeka, lebo l'udská prirodzenost' obsahuje jednak prírodné danosti a možnosti človeka i jeho spoločenské predpoklady a súvislosti. Znamená to fakt, že pokrok je viazaný na výchovu a vzdelávanie ako základné kategórie pedagogiky a súčast' kultúry. V tomto zmysle "l'udská osoba môže dosiahnut' plnost' pravej l'udskosti jedine pomocou kultúry, t.j. kultivovaním prirodzených bohatstiev a hodnôt (SirotováMichvocíkova, 2016). Pod pojmom kultúra sa rozumie všetko to, čím človek cibrí a rozvíja soje mnohoraké duševné a telesné vlohy, čím sa usiluje poznávaním 
a prácou podrobit' si sám svet, čím robí l’udskejším spoločenský život tak v rodine a ako aj v celom občianskom spoločenstve zdokonal'ovaním mravov a ustanovizní. A napokon, čím v priebehu vekov svojimi dielami prejavuje, vyjadruje a uchováva vel'ké duchovné zážitky a snahy, aby mohli slúžit mnohým, ba celému l'udskému pokoleniu“ ( Balák, 2006). Pedagogika je veda so stáročným vývojom, od obdobia starovekých štátov po súčasnost'. Podstatná systemizácia pedagogiky, ako vedy, bola realizovaná v 17. storočí prácami učitel'a národov J. A. Komenského, pokračovala aktivitami J. F. Herbarta a prácami d’alších učencov, ktorí dokázali, že sústredenie pozornosti na človeka je vkladom do budúcnosti jednotlivcov, národov i l'udstva vôbec. Ved' v súčasnosti je jednoznačné historické poznanie, že krajiny, ktoré investovali do výchovy a vzdelávania výnimočne vynikli a vynikajú v kultúrnom, ekonomickom a morálnom rozvoji s vplyvom na kvalitu života. V postupnom historickom vývoji bol rozpracovaný predmet, metódy, teória, i obsah pedagogiky, boli definované odborné pedagogické pojmy, boli objasnené úlohy národného, ale aj globálneho vzdelávania a výchovy. Vzdelávanie a výchova prispievajú ku kultúre života každého človeka, k zbližovaniu l’udí, objektívnemu vnímaniu sveta, spájaniu $\mathrm{v}$ rozdielnostiach a budúcnosti.

Poznanie je vhodné ako základ pre definovanie pedagogiky, ktorú M. Zelina (2004) uvádza slovami, že „pedagogika, možno povedat' v celom svete, je skôr vedou a poslaním o l'udskosti, humanite a sociálnej spravodlivosti vo svete“. Dosiahnutie týchto noriem v medzil'udských vzt’ahoch je viazané skutočne na poznanie človeka, jeho vzdelávanie i výchovu v zmysle najlepších všel'udských hodnôt. Poskytovaním vzdelávania, poznaním faktov o prírode, spoločnosti i človeku, poskytovaním vzoru, príkladov i správnou komunikáciou, ktorými sú utvárané životné postoje a vzt'ahy viazané predovšetkým na myslenie. Myslenie a vlastné zážitky umožňujú vychovávaným chápat' svet pri ich prirodzenej hravosti, zvedavosti, predstavivosti, dôverčivosti i kritickosti. Znaky, ktoré je potrebné odborne usmerňovat' v procese výchovy a vzdelávania nielen $\mathrm{v}$ škole, ale aj $\mathrm{v}$ rodine, širšom alebo užšom spoločenskom prostredí, čo bez vedeckého poznania nie je možné (Pushkarev, Pushkareva, 2018). Z aspektu teoretického i praktického významu pedagogiky je nutné prijat' názor, že je „,v odbornom význame veda a výskum zaoberajúci sa vzdelávaním a výchovou v najrozličnejších sférach života spoločnosti. Nie je teda viazaná len na vzdelávanie $\mathrm{v}$ školských inštitúciách a na populáciu detí a mládeže. V zahraničí sa vo význame pedagogiky často používa termín pedagogická veda (educational science, Erziehungswissenschaft)“ (Prucha, Walterova, Mares 2003). Celospoločenský význam pedagogiky zdôrazňuje aj Terminologický a výkladový slovník Organizácia a manažment školstva (Obdrzalek, Horvathova a kol. 2004) konštatovaním, že pedagogika je „veda o výchove a vzdelávaní nielen v škole, ale aj v najrôznejších oblastiach života spoločnosti. Skúma podstatu a zákonitosti výchovy a vzdelávania ako spoločenského javu a formovania procesu vytvárania osobnosti človeka, jeho schopností a vlastností. Objasňuje ciele, obsah, podmienky, metódy a prostriedky výchovy a na základe zovšeobecnených empirických skúseností a poznaných zákonitostí stanovuje pedagogické zásady a prístupy pre výchovnú a vzdelávaciu činnost"“.

Pedagogika zasahuje do rozvoja, vzt’ahov i správania všetkých l’udí. Je procesuálne i obsahovo orientovaná na najvýraznejšiu bytost' sveta i života vôbec, na človeka a jej úlohou, ako vedy o človeku, je riešit' a nachádzat' vhodné a účinné formy, metódy a prostriedky utvárania osobnosti človeka. Využívat' pritom musí aj poznanie dedičných predpokladov a poznanie vplyvu prostredia a orientáciu na rozvoj záujmu o školu, vzdelávanie i vzdelanie, slušné správanie, lebo „bez vyučovania je výchova prázdna, môže sa stat' moralizovaním a často skízava do emotívnej rétoriky“ (Pelcova 2010), čo je v rozpore s prirodzenost'ou človeka. 
A čo je prirodzenost' človeka? Prirodzenost' človeka je prejav životných aktivít a každodennej činnosti. Znamená reálnu túžbu človeka po prijímaní života so všetkými jeho súvislost'ami, túžbu po poznaní, št’astí, blízkosti iného, blízkeho alebo cudzieho človeka, snahu uspokojit' vlastné životné potreby i poznanie seba samého.

K prirodzenosti človeka patrí aj túžba po vlastnej dôstojnosti ako nezamenitel'nej životnej hodnoty, ktorá môže byt' zabezpečená len v podmienkach humanity, demokracie a rešpektovania l'udských práv. K nim sa ako prirodzená túžba človeka prirad'uje aj mier, pravda a spravodlivost' ako predpoklady štastného a obsažného života na základe zdravia, ale aj túžba po ovládaní iných l’udí, moc, ziskuchtivost', či egoizmus. Žiadna z týchto prirodzených hodnôt nie je nemenná a je potrebné sa o ňu snažit' alebo ju eliminovat' s primeraným pôsobením, ktoré môže aktivizovat' práve vzdelávanie a výchova, lebo človek túži predovšetkým poznávat' a byt' uznávaný a poznaný. To je identita, ktorá „, predpokladá vzájomné l'udské spolužitie a konfrontáciu s inými“" (Tomasovicova, 2006).A v záujme tejto túžby je ochotný aj riskovat', obetovat' sa vo výskume, v práci, myslení i konaní. Bez tohto záujmu, zvedavosti i úcty voči l'udstvu by neboli objavy a činy Marie Curie Sklodowskej, Nielsa Bohra, J. A. Komenského, Fridricha Herbarta, Davida Livingstona, Jurija Gagarina, Neil Amstronga a radu d’alších známych, menej známych alebo celkom neznámych l'udí, ktorí aspoň čast'ou vlastnej práce prispeli ku kvalite života a budúcnosti jedného celku nazývaného l'udstvo. L'udstva, ktoré je vnímané ako l'udské bytie ako skupina, alebo kvalita, podmienka alebo fakt bytia l'udskosti ( Webster's, 1984).

Aj v tomto zmysle platí, že ,základnou axiómou každej pedagogiky by mala byt' vel'ká zásada, že neprávosti sa nikdy nedajú odstránit' púhym negatívnym bojom proti nim, zákazmi, výčitkami, či rozhorčením, lebo tie skôr pomáhajú $\mathrm{k}$ ich prehíbeniu, než by ich prekonávali, ale ich odstraňovat' len nepriamo prebúdzaním novej lásky a odvahy ku cnosti a všetkým kladným hodnotám“ (Scheller 2003). V tomto zmysle je nutné nachádzat' poučenie nielen v minulosti, ale aj v súčasnosti, aby bola zabezpečená budúcnost' človeka a l'udstva s prirodzeným právom života ako najväčšej hodnoty sveta a zachovávaním, či upevňovaním zdravia ako najvýraznejšej hodnoty každého človeka. V záujme budúcnosti sa vyžaduje dynamické myslenie, spojenie poznania s pravdou, rovnostou a právom, umením, etiketou, estetikou, spoločenským životom, či telesnou, náboženskou alebo pracovnou výchovou. Podstatná je aj potreba rozvoja zručností a komunikácie pri poznávaní jednoty a rozdielnosti l'udí v súlade s prírodnými i spoločenskými podmienkami. Všetky predstavy a ciele budú dosiahnuté vtedy, ak skutočným ciel'om a subjektom spoločenského života bude človek s naplnením jeho prirodzeného záujmu a potreby rešpektu a úcty voči nemu samotnému. Lebo , pre človeka ako druh je totiž charakteristická taká regulácia, ktorá je výsledkom trojakého tvarovania biologického, spoločensko-kultúrneho a kognitívno-vôlového. L’udskú reguláciu konania a maslenia preto treba skúmat' vo vzt'ahu k danej kultúre, k všeobecnej neurobiológii, ako aj k psychickým štruktúram samotného jedinca“ ( Plichtová, 2004).

\section{Bibliographic references}

BALAK, R. 2006. Kulturna identita vo vztahu k ludskej prirodzenosti. In. Sulavikova, B., Visnovsky, E.(eds.). Ludska prirodzenost a kulturna identita. Bratislava: Iris, s. $227-251$.

BREZINKA, W. 1996. Filozoficke zaklady vychovy, Praha: Zvon.

CIC, M. 2001 Cesta k demokracii. Pezinok: Format.

DANEK, J. 2011. Uvod do filozofie vychovy. Praha: UJAK.

DANEK, J. 2018. Osobnost, spolocnost, vychova. Nadlak: Editura Ivan Krasko.

FROLOV, T. 1986. Filozoficky slovnik. Bratislava: Pravda. 
GAL, E. 2004. Lutujem, ale vasa dusa prave zomrela. Antropos - casopis pre humanitne a socialne poznanie. $1, \mathrm{n} .2, \mathrm{pp} .13-16$.

GEISS, J. 2005. Dejiny sveta v souvislostech. Praha: Ivo Zelezny.

KOREC, J. CH. 2007. Clovek, tvor nahodny? Bratislava: Luc.

KOSOVA, B. 2008. Problemy filozofie edukacie a teorie edukacie (vychovy). In: Danek, J. (ed.): Vychova v pedagogickom vyskume a praxi. Trnava: UCM, $19-27$.

KOSOVA, B. 2013. Filozoficke a globalne suvislosti edukacie. Banska Bystrica: UMB.

KOVAC, D. 2002. Osobnost - od formovania k sebautvaraniu. Bratislava: UEP SAV. KUDLACOVA, B. 2006. Fenomen vychovy. Bratislava: Veda.

KUDLACOVA, B. 2009. Dejiny pedagogickeho myslenia I. Trnava: Universitatis Tyrnaviensis, Veda.

LORENZ, K. 1980. 8 smrtelnych hrichu. Praha: Pyramida.

MALA CESKOSLOVENSKA ENCYKLOPEDIE I. 1984. Praha: Academia.

MUZDYBAJEV, K. 1983: Psichologija otvetstvennosti. Leningrad: Nauka.

OBDRZALEK, Z. - HORVATHOVA, K. a kol. 2004. Organizacia a manazment skolstva. Bratislava: SPN.

PALOUS, R. 1991. K filosofii vychovy. Praha: SPN.

PELCOVA, N. 2010. Vzorce lidstvi. Filozoficke zaklady pedagogicke antropologie. Praha: Portal.

PELIKAN, J. 2007. Hledani teziste vychovy. Praha : Karolinum.

PEREGRIN, J. 2008. Filozofie pre normalni lidi. Praha Dokoran.

PLICHTOVA, J. 2004. O dvojakej prirodzenosti cloveka. Filozofia, 59, 2004 c.2, s. 1000-109.

PRUCHA, J. - WALTEROVA, E. - MARES, J. 2003. Pedagogicky slovnik. Praha: Portal.

PUSHKAREV, V. - PUSHKAREVA, E.A. 2018. Philosophical interpretation of knowledge and information: knowledge value and information diversity in modern communication. In XLinguae Vol 11, nr 2, pp 176-184.

RUISEL, J. 2005. Mudrost v zrkadle vekov: Bratislava: Ikar.

SEDOVA, T. 2014. O zle, nasila a moci, ich vztahu a odlisnosti - traja autori, tri perspektivy. Filozofia, 69, 2014 c.9, s.777-785.

SCHELLER, M. 1968. Misto cloveka v kosmu. Praha: Academia.

SCHELLER,M. 2003. Muj filosoficky pohled na svet. Praha: Vysehrad.

SIDOROV, N. R. 2007. Filosofija obrazovanija. Moskva: Piter.

SIROTOVA, M. 2018. Multicultural Education and Educational Process at Slovak Universities. In Journal of Language and Cultural Education. Vol.6 nr 1 p 158-167.

SIROTOVA, M. - MICHVOCIKOVA, V. 2016. Multicultural society from view of university students. In Journal of Language and Cultural Education. Vol.4 nr 1 p 3245.

SKALKOVA, J. 2007. Obecna didaktika. Praha: Grada.

STEINDL, R. 2000. O smrti. Bratislava: IRIS.

SULAVIKOVA, B. 2006. Prirodzenost cloveka v intenciach moderneho humanizmu. In. Sulavikova, B, Visnovsky, E.(eds.) Ludska prirodzenost a kulturna identita. Bratislava: Iris.

TOMASOVICOVA, J. 2006. Zapas o identitu cloveka. In. Sulavikova, B., Visnovsky, E. (eds.). Ludska prirodzenost a kulturna identita. Bratislava: Iris, s.165-186).

VISNOVSKY, E. 2007. Ludska prirodzenost a kulturna identita. http ://www.kvsbk.sov.sk. 16.4.2007.

Webster's II.New Riverside university dictionary. 1984. Boston: The Riverside Publishing Company.

ZELINA, M. 1996. Strategie a metody rozvoja osobnosti dietata. Bratislava: IRIS.

XLinguae, Volume 12, Issue 4, October 2019, ISSN 1337-8384, eISSN 2453-711X 
ZELINA, M. 2004. Teorie vychovy alebo hladanie dobra. Bratislava: SPN.

Words: 5389

Characters: 38856 (21,59 standard pages)

Prof. PaedDr. Ján Danek, CSc.

Ss. Cyril and Method University in Trnava

Faculty of Arts

Department of Pedagogy

Nám. J Herdu 2

91701 Trnava

Slovakia

jan.danek@ucm.sk 